\title{
THERMAL-CYCLING BEHAVIOR OF CONiCrAIY BONDS COATED WITH THERMAL BARRIER COATINGS (TBCs) PRODUCED WITH ATMOSPHERIC PLASMA SPRAYING (APS)
}

\author{
OBNAŠANJE CONiCrAIY PREVLEKE MED TERMIČNIM \\ UTRUJANJEM
}

\author{
Mustafa Kaplan ${ }^{1}$, Mesut Uyaner ${ }^{2}$, Abdullah Cahit Karaoglanli ${ }^{3}$ \\ ${ }^{1}$ Selcuk University, Department of Metallurgical and Materials Engineering, Graduate School of Natural and Applied Sciences, Konya, Turkey \\ ${ }^{2}$ Necmettin Erbakan University, Faculty of Aeronautics and Astronautics, Department of Aeronautical Engineering, Konya, Turkey \\ ${ }^{3}$ Bartin University, Faculty of Engineering, Department of Metallurgical and Materials Engineering, Bartin, Turkey \\ mkaplan5442@gmail.com
}

Prejem rokopisa - received: 2017-01-23; sprejem za objavo - accepted for publication: 2017-05-12

doi:10.17222/mit.2017.024

Thermal barrier coatings (TBCs) are commonly applied as a thermal insulation in order to protect against environmental influences in the components of high-temperature gas turbines and jet engines. Gas-turbine components are affected by aggressive conditions of the environment during the service, being subjected to failures such as corrosion, thermal shock and oxidation. Plasma-spray technology is used to produce metallic bonds and ceramic top coats as a cost-effective method to prolong the lifetime of TBCs. In the present research, CoNiCrAlY bond-coat and YSZ top-coat powders included in the TBCs were deposited onto Inconel 718 superalloy substrates using atmospheric plasma spraying (APS). The TBCs were exposed to a furnace cycling test at $1150{ }^{\circ} \mathrm{C}$ and one-hour cycles. The presence of porosity and cracks facilitating the diffusion of oxygen in the top-coating structure led to the formation of thermally grown oxides (TGOs) at the interface. In addition, the most effective factors of failures were the formation and growth of mixed oxides at the bond/top-coat interface and the presence of imperfections. According to the test results, an increasing number of thermal cycles resulted in a decrease in the lifetime of the TBCs related to the sintering of the top coating due to the effect of high temperature.

Keywords: thermal barrier coatings (TBCs), thermal cycling, Inconel 718 superalloy, atmospheric plasma spraying (APS), CoNiCrAlY, ytrria-stabilized zirconia (YSZ)

Prevleke s toplotno pregrado (angl. TBCs) se običajno uporabljajo kot toplotna izolacija, ki ščiti komponente visoko temperaturnih plinskih turbin ali reaktivnih motorjev. Na komponente plinskih turbin vplivajo agresivni vplivi okolja, katerim so izpostavljene med obratovanjem, zato pride do okvar, kot so: korozija, termični šok in oksidacija. Tehnologija plazemskega naprševanja je cenovno ugodna tehnologija za izdelavo kovinskih in keramičnih prevlek. V članku avtorji predstavljajo raziskavo v kateri sta bila na podlago iz zlitine Inconel $718 \mathrm{~s}$ tehnologijo plazemskega naprševanja v zračni atmosferi nanešena vezivna prevleka CoNiCrAlY in prekrivni sloj iz YSZ prahu. Izdelani prevleki sta bili nato izpostavljeni termičnem utrujanju v peči pri $1150{ }^{\circ} \mathrm{C}$ z večimi enournimi cikli. Prisotnost poroznosti in razpok olajša difuzijo kisika v zgornjo plast prevleke kar vodi do nastanka termično induciranega oksida (TGO) na površini prevleke. Poleg tega sta bila najpomembnejša dejavnika za nastanek napak tvorba mešanih oksidov na meji med vezno in vrhno plastjo ter prisotnost drugih nepravilnosti. Rezultati preizkusov so pokazali, da povečanje števila termičnih ciklov zmanjšuje dobo trajanja TBC prevlek, zaradi sintranja zgornje plasti pri povišanih temperaturah.

Ključne besede: prevleke s toplotno pregrado, toplotni (termični) cikel, superzlitina Inconel 718, plazemsko naprševanje, CoNiCrAlY, cirkon stabiliziran z itrijem

\section{INTRODUCTION}

Atmospheric plasma spraying (APS) is one of the most important methods in the thermal-spray family. The APS technique, which is a type of the plasma spray technique, provide many advantages, such as an economic, quick and easy production; besides, almost all materials can be sprayed with this method. Plasma-sprayed particles quickly cool down from very high temperatures to low temperatures. Plasma-spray coatings consist of microstructured, layered and porous structures. ${ }^{1,2}$

Thermal barrier coatings (TBCs) are widely employed in gas turbines and its components operating at high-temperature service conditions. The main function of TBCs is to provide a protective thermal shield to protect the main material components, especially turbine blades and vanes, from the negative effects caused by high temperatures in the environment. There are three main layers in TBC systems, including a nickel-based superalloy substrate, an MCrAlY metallic bond coat and partially yttria-stabilized zirconia (YSZ), acting as the ceramic top coat. ${ }^{3,4}$ The bond coat, which consist of $\operatorname{MCrAlY}(\mathrm{M}=\mathrm{Ni}$ and/or $\mathrm{Co})$, is extensively applied to minimize the thermal mismatch between the superalloy substrate and the ceramic top coat. ${ }^{5,6}$

TBCs are subject to sudden temperature changes and thermal stress during service conditions. In high-temperature applications, TBCs are adversely affected and tend to suffer because of failures such as oxidation, hot corrosion and thermal cycling/shock so that they lose structural integrity. Residual stresses due to the thermalexpansion mismatch during the cooling and sintering of 
M. KAPLAN et al.: THERMAL-CYCLING BEHAVIOR OF CoNiCrAIY BONDS COATED WITH THERMAL BARRIER ...

the top coat, and oxidation of the bond coating cause the coating to become damaged during thermal cycling. ${ }^{7,8}$

In this study, the TBC system consists of a CoNiCrAlY metallic bond and YSZ ceramic top coat deposited with the APS technique on an Inconel 718 superalloy substrate. The effects of oxidation and TGO-growth behavior on the thermal durability were investigated through a furnace thermal cyclic test. The microstructure evolution and thermal durability were evaluated before and after the furnace thermal-cycling tests.

\section{EXPERIMENTAL PART}

\subsection{Material}

The Inconel 718 nickel-based superalloy was used as the substrate material. Superalloy disk-shaped samples with a diameter of $25.4 \mathrm{~mm}$ and thicknesses of $4 \mathrm{~mm}$ were used as substrates. The chemical composition of the nickel-based superalloy substrate is given in Table $\mathbf{1}$.

Table 1: Chemical composition of Inconel 718 Ni-based superalloy 9

\begin{tabular}{|c|c|c|c|c|c|c|c|}
\hline \multicolumn{6}{|c|}{ Elements, Chemical Composition, in mass fractions $(w / \%)$} \\
\hline $\mathrm{Ni}$ & $\mathrm{Cr}$ & $\mathrm{Nb}$ & $\mathrm{Ti}$ & $\mathrm{Mo}$ & $\mathrm{Al}$ & $\mathrm{Co}$ & $\mathrm{Si}$ \\
\hline 53.53 & 18.45 & 5.31 & 0.95 & 3.02 & 0.48 & 0.27 & 0.09 \\
\hline $\mathrm{Cu}$ & $\mathrm{Mn}$ & $\mathrm{C}$ & $\mathrm{Ta}$ & $\mathrm{P}$ & $\mathrm{B}$ & $\mathrm{S}$ & Fe \\
\hline 0.04 & 0.06 & 0.03 & 0.005 & 0.007 & 0.005 & 0.001 & Balance \\
\hline
\end{tabular}

\subsection{Spraying processes}

Commercial CoNiCrAlY metallic bond-coat powder (Amdry 9951, Sulzer-Metco) with a 5-37 $\mu \mathrm{m}$ particle size and $\mathrm{ZrO}_{2}+8 \% \mathrm{Y}_{2} \mathrm{O}_{3}$ (YSZ) ceramic top-coat powder (Metco 204NS, Sulzer Metco) with a $-45+20 \mu \mathrm{m}$ particle size were used as the feedstocks. As previously mentioned, the APS technique was used for depositing both the metallic bond and ceramic top coatings. The top layer of YSZ with a thickness of $300 \mu \mathrm{m}$ was applied on the CoNiCrAlY layer with a thickness of $100 \mu \mathrm{m}$ on the superalloy substrates.

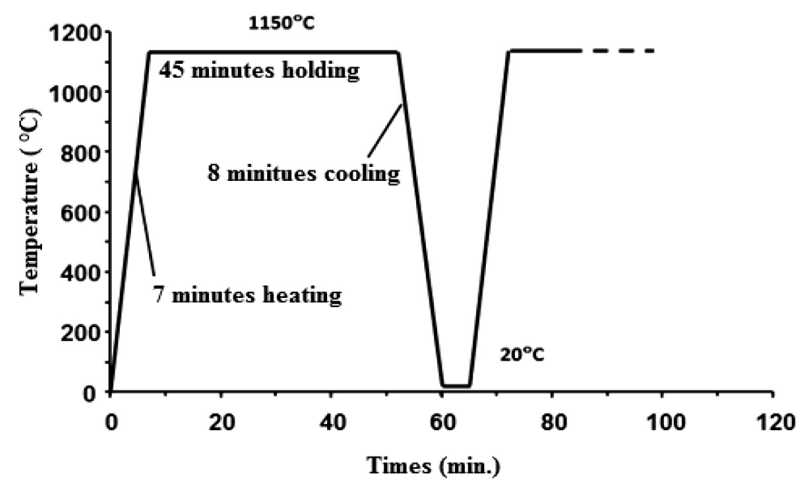

Figure 1: Thermal-cycling diagram during the furnace cycling test

\subsection{Furnace thermal-cycling test}

The lifetime of the TBCs tested with the furnace thermal-cycling test using rapid temperature furnace $1710 \mathrm{BL}$ was as follows: The samples were heated to $1150{ }^{\circ} \mathrm{C}$ in $7 \mathrm{~min}$, held at this temperature for $45 \mathrm{~min}$ and then cooled to $20{ }^{\circ} \mathrm{C}$ in air within $8 \mathrm{~min}$. The thermal-loading diagram of the samples coated during thermal cycling is given in Figure 1. During isothermaloxidation cycles, the temperature changes in the working furnace did not exceed $5{ }^{\circ} \mathrm{C}$. The coating lifetime was determined with the thermal cycling carried out until the cracking point of the outer ceramic layer. This was considered to be cracked when $25 \%$ of the sample surface was blistering. The surface failure was visually determined based on the percentage of the separation of the outer ceramic layer from the sample surface. At the end of the thermal-cycling tests, the samples were investigated from both the top surface and cross-sectional area via a scanning-electron-microscopy (SEM) analysis.

\section{RESULTS AND DISCUSSION}

\subsection{As-sprayed TBC}

A SEM microstructure image of an as-deposited TBC is shown in Figure 2. The APS-applied CoNiCrAlY metallic bond and the YSZ top coat exhibit a porous structure and some cracks and open discontinuities due to the deposition process. The metallic-bond and topcoat structures show typically characteristic properties of the plasma-spray technique.

In Figure 3, the top surface of the TBC is shown. There are some micro-cracks due to heating and rapid cooling of the sprayed particles during the deposition process as well as melted and unmelted particles.

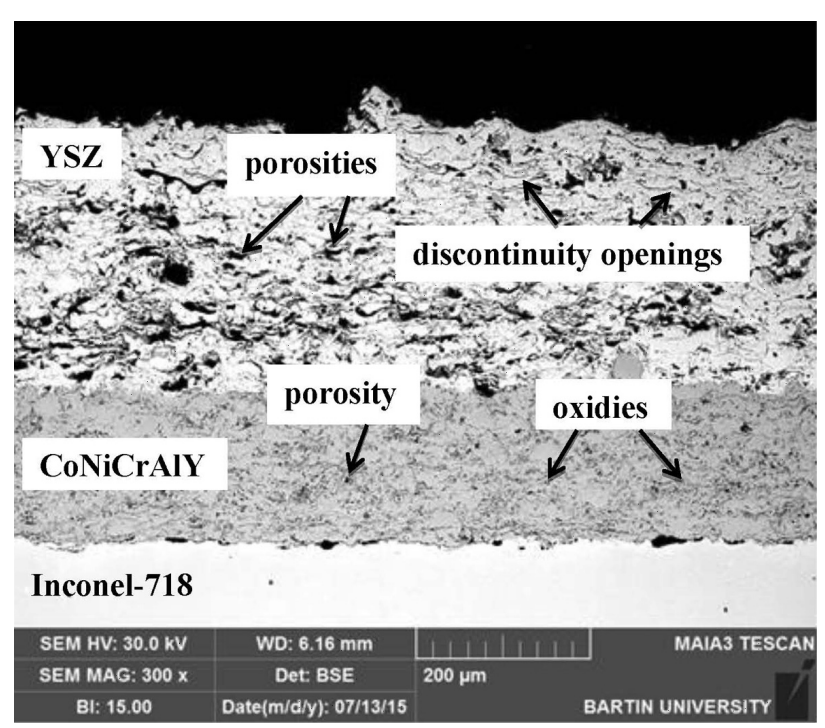

Figure 2: As-deposited TBC cross-sectional SEM microstructure 


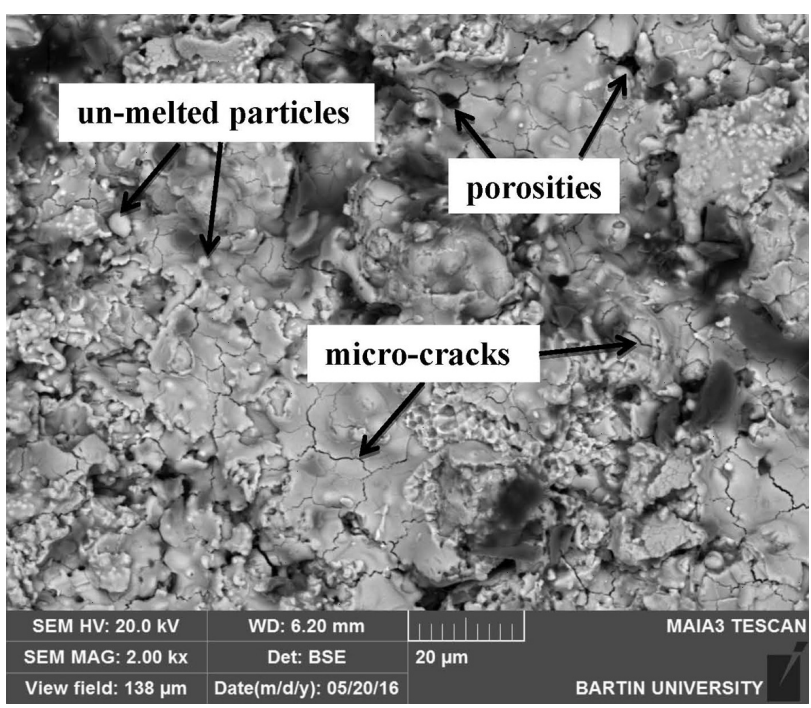

Figure 3: Top-coat SEM image of the as-sprayed TBC

\subsection{Thermal-cycling test of the coated specimens}

At high temperatures, oxygen can easily diffuse from the top coat to the bond coat due to the ionic conductivity of YSZ. Also, the coating includes many imperfections such as cracks and porosity, which accelerate the penetration of oxygen to the metallic bond coat. As a result, the bond coat oxidizes easily at high temperatures in spite of the ceramic coat. According to the Ellingham diagram, $\mathrm{Y}$ and $\mathrm{Al}$ are the elements that enter the first reaction with oxygen in the CoNiCrAlY bond coat due to low-standard free energies. With the effect of high temperature, the particles are still oxidized in flight and during the deposition on the substrate material. ${ }^{10}$

Using the APS method, there are many internal oxide formations in the coating because of the excessively high temperatures due to plasma during the deposition of the coating. Since the concentration of the $\mathrm{Y}$ element is much lower than those of the other elements, $\mathrm{Y}$ can be entirely depleted. Thus, after the deposition of a TBC, $\mathrm{Al}$ is oxidized at the interface and $\mathrm{Al}_{2} \mathrm{O}_{3}$ is formed. ${ }^{11-13}$

In the early stages of the cyclic oxidation, the TGO layer mainly occurred as the $\mathrm{Al}_{2} \mathrm{O}_{3}$ phase. This oxidation causes thermal stresses at the interface between the bond and the top coat due to both the phase transformations of $\mathrm{Al}_{2} \mathrm{O}_{3}(\gamma, \delta, \theta$ and $\alpha)$ and a lower thermal-expansion coefficient compared to $\mathrm{YSZ}$. $\mathrm{Al}_{2} \mathrm{O}_{3}$ (especially in the $\alpha-\mathrm{Al}_{2} \mathrm{O}_{3}$ form) is thermodynamically a very stable phase compared to the other phases such as $\mathrm{Cr}_{2} \mathrm{O}_{3},(\mathrm{Co}, \mathrm{Ni}) \mathrm{O}$ or $(\mathrm{Co}, \mathrm{Ni})(\mathrm{Al}, \mathrm{Cr})_{2} \mathrm{O}_{4} \cdot{ }^{13} \mathrm{In}$ addition, it provides a better resistance against the oxygen expansion into the bond coat. Depending on the time, the $\mathrm{Al}$ concentration decreases to a critical level and $\mathrm{Cr}_{2} \mathrm{O}_{3}$ and $(\mathrm{Co}, \mathrm{Ni}) \mathrm{O}$ phases form at the interface. Afterwards, these oxides react with $\mathrm{Al}_{2} \mathrm{O}_{3}$ and spinel phases occur. The thermal-expansion coefficient of the spinel phases is relatively lower than that of $\mathrm{Al}_{2} \mathrm{O}_{3}$, which means it leads to a higher stress. ${ }^{14,15}$
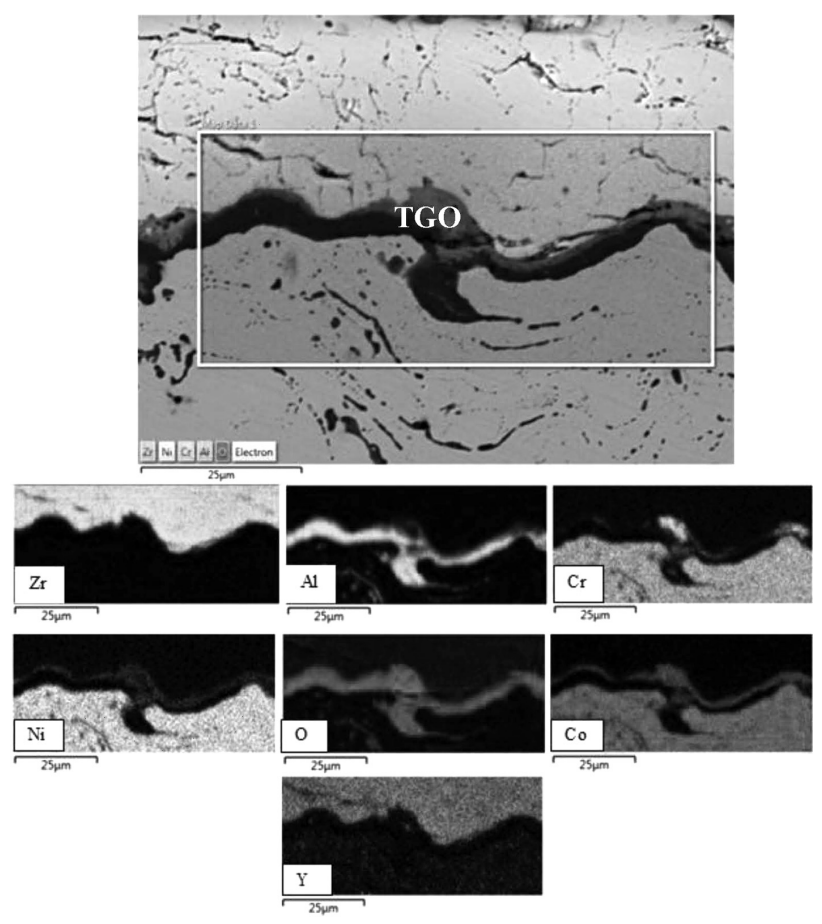

Figure 4: Elemental mapping microstructure belonging to the YSZ TBC after a 40-h thermal-cycling test

In addition, the spinel phases grow faster than $\mathrm{Al}_{2} \mathrm{O}_{3}$ and show larger volume changes. ${ }^{16}$

In Figure 4, an elemental mapping microstructure belonging to the YSZ TBC after a 40-h thermal-cycling test is shown. The coating structure almost preserved its uniformity. At the interface, the $\mathrm{Al}_{2} \mathrm{O}_{3}$ phase is dominant and a mixture of oxide formations like $\mathrm{Cr}_{2} \mathrm{O}_{3},(\mathrm{Co}, \mathrm{Ni}) \mathrm{O}$ and spinels can be observed. In the bond coat, dark stringers represent the $\mathrm{Al}_{2} \mathrm{O}_{3}$ phase. In addition, the top coat was sintered due to the effect of high temperature

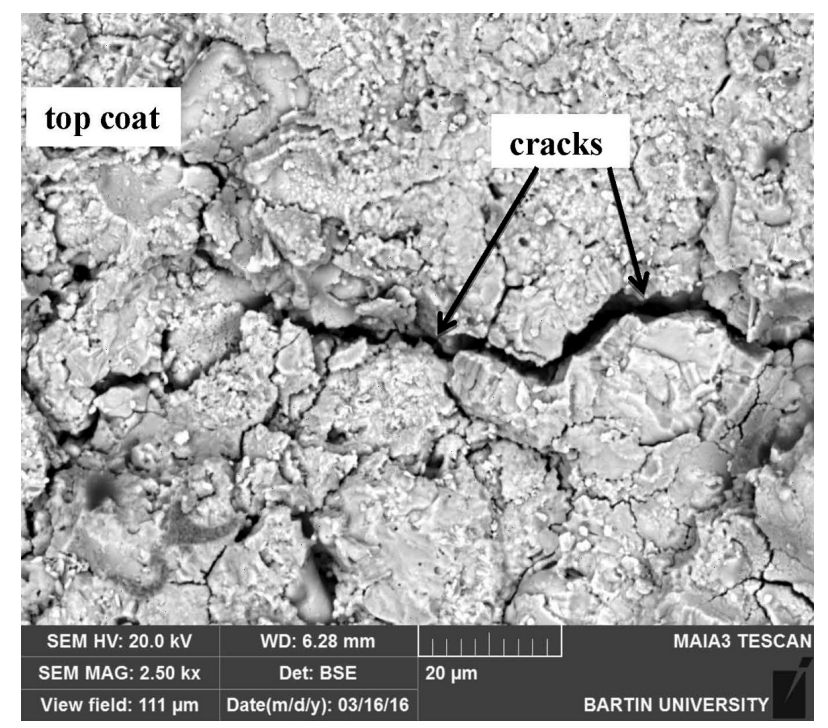

Figure 5: Top-surface SEM image of the TBC after the thermalcycling test 
M. KAPLAN et al.: THERMAL-CYCLING BEHAVIOR OF CoNiCrAIY BONDS COATED WITH THERMAL BARRIER ...

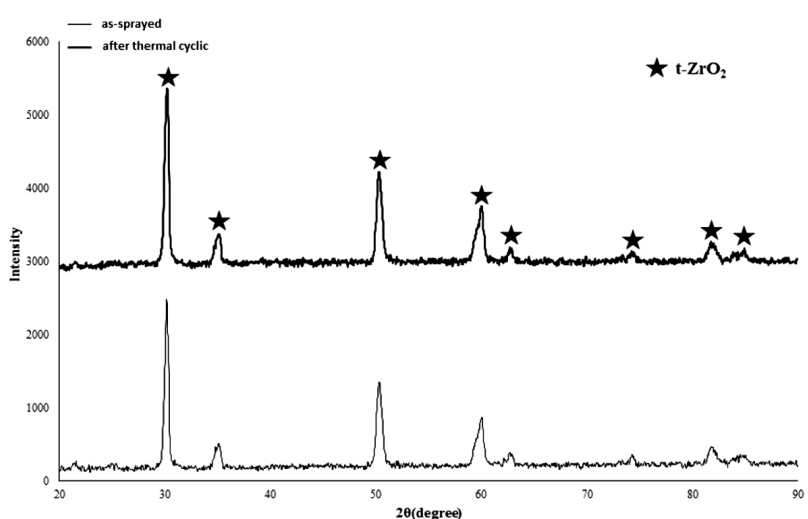

Figure 6: XRD analysis of the TBC before and after the thermalcycling test

depending on time. This can be explained with decreasing discontinuity openings.

In Figure 5, a top-surface SEM image of the TBC after the thermal-cycling test is given. After 40 thermal cycles, the top-surface crack area of the TBC covers approximately $25 \%$. In Figure 5, a failed surface of the TBC is shown. According to Figure 5, there are large crack formations and sintered areas.

Figure 6 shows that there is only one phase in the as-sprayed TBC. After the thermal-cycling test, there is not any phase transformation so the structure is similar to the as-sprayed TBC. The semi-stable tetragonal $\mathrm{ZrO}_{2}$ phase is durable up to approximately $1200{ }^{\circ} \mathrm{C}$, which means that the crack propagation does not progress into the bond coat. ${ }^{8}$ This can also be understood from a cross-sectional SEM image of the failed TBC.

J. A. Haynes et al. ${ }^{17}$ applied furnace thermal-cycling tests to YSZ TBCs including a NiCrAlY bond coat produced with the APS method. The tests were carried out for one hour in a furnace at $1150{ }^{\circ} \mathrm{C}$ with periods of 15-min heating and 30-min cooling. The test result shows that after 100 thermal cycles, the APS TBCs failed. However, in the present study, the heating and cooling times of the thermal-cycling tests are shorter. Thus, the CoNiCrAlY TBC is exposed to damage earlier than in the above study. R. Chen et al. used the APS technique to produce a CoNiCrAlY bond coated with the YSZ TBC on an Inconel 625 substrate. Their thermal-cycling test at $1050{ }^{\circ} \mathrm{C}$ showed a parabolic TGO growth. The growth rate of the TGO structure increased proportionally as the thermal-cycling period increased. This result supports the present study.

A. El-Turki et al. ${ }^{18}$ studied the thermal-cycling behavior of a VPS NiCoCrAlY bond coated with APS YSZ at $1050{ }^{\circ} \mathrm{C}$, with 25 -min heating, 300-h holding and 30-min cooling. The TBCs were damaged after 21 cycles. The damage of the TBCs started at the same time as the damage to TGO interface areas. The use of the VPS technique allowed a low porosity and oxidation during the deposition of the bond coat, and their total holding time was very long compared to the present study. ${ }^{19}$ J. Sun et al. ${ }^{20}$ produced their bond coat using the HVOF technique; afterwards they carried out the deposition of
APS YSZ. Their thermal cycling was performed at 1100 ${ }^{\circ} \mathrm{C}$ for one hour, with 10-min cooling. After 30 thermal cycles, the TBC underwent a significant failure. In contrast, the present-study condition is more destructive, but the thermal-cycling lifetime is longer. As a result, the used bond-coat powder type, production technique and thermal-cycling conditions can cause significant differences in the lifetime of TBCs. ${ }^{20}$ In the present study, the APS TBC separated from the bond-coat surface of the ceramic top coat after $40 \mathrm{~h}$ of the thermal cycling and was spalled and damaged. Furthermore, a TGO structure formed during the thermal cycling, causing failure of the TBC systems. The growth of the oxide layer formed the TGO structure and an increase in the stresses increased the failure formation.

\section{CONCLUSIONS}

In this study, TBCs including CoNiCrAlY bonds and YSZ were deposited using the APS technique. Furnace thermal-cycling tests were performed to predict the thermal-cycling lifetime of the TBCs and to observe their microstructural changes. The results obtained at the end of the observations are given below.

TBCs were damaged, with their cracks covering $25 \%$ of the top coat after 40 cycles.

The most effective factor of failure was the formation of mixed oxides and spinels at the interface of the bond and the top coat, according to the cross-sectional investigations.

The porosity and cracks of the top coat caused the formation of TGOs at the interface.

The top coat was sintered as a result of high temperature depending on time.

At the interface, the $\mathrm{Al}_{2} \mathrm{O}_{3}$ phase is dominant, but a mixture of oxide formations like $\mathrm{Cr}_{2} \mathrm{O}_{3}$, ( $\left.\mathrm{Co}, \mathrm{Ni}\right) \mathrm{O}$ and spinels is also observed. In the bond coat, dark stringers represent the $\mathrm{Al}_{2} \mathrm{O}_{3}$ phase. The mixture of oxides formed at the interface was mainly responsible for the failure of the TBCs after the thermal cycling.

\section{Acknowledgements}

The present study was derived from the Ph.D. thesis of Mustafa Kaplan at the Selcuk University Graduate School of Natural and Applied Sciences, Konya, Turkey. The study was also supported by Selcuk University Scientific Research Projects under the Grant Number of 15201071 .

\section{REFERENCES}

${ }^{1}$ L. Pawlowski, The Science and Engineering of Thermal Spray Coatings, $2^{\text {nd }}$ ed., John Wiley \& Sons, England, 2008, 656

${ }^{2}$ K. M. Doleker, A. C. Karaoglanli, Comparison of oxidation behavior of shot-peened plasma spray coatings with cold gas dynamic spray coatings, Oxidation of Metals, (2016), 1-12, doi:10.1007/s11085016-9691-3 


\section{MATERIALI IN TEHNOLOGIJE/MATERIALS AND TECHNOLOGY (1967-2017) - 50 LET/50 YEARS}

\section{KAPLAN et al.: THERMAL-CYCLING BEHAVIOR OF CoNiCrAIY BONDS COATED WITH THERMAL BARRIER ...}

${ }^{3}$ K. E. Schneider, V. E. Belashchenko, M. Dratwinski, S. Siegmann, A. Zagorski, Thermal spraying for power generation components, John Wiley \& Sons, England, 2006, 285

${ }^{4}$ Z. Gao, G. Jin, Z. Cai, Y. Fu, X. Cui, Thermal cycling property of supersonic atmospheric plasma sprayed thermal barrier coatings reinforced by Ni-coated YSZ fibers, Surface and Coatings Technology, (2017), doi:10.1016/j.surfcoat.2017.01.041

${ }^{5}$ A. C. Karaoglanli, K. M. Doleker, B. Demirel, A. Turk, R. Varol, Effect of shot peening on the oxidation behavior of thermal barrier coatings, Applied Surface Science, 354 (2015) 2, 314-322, doi:10.1016/j.apsusc.2015.06.113

${ }^{6}$ A. C. Karaoglanli, K. M. Doleker, Y. Ozgurluk, State of the art thermal barrier coating (TBC) materials and TBC failure mechanisms, properties and characterization of modern materials, Adv. Struct. Mater., 33 (2017), 441-452, doi:10.1007/978-981-10-1602-834

${ }^{7}$ A. N. Khan, J. Lu, Behavior of air plasma sprayed thermal barrier coatings, subject to intense thermal cycling, Surface and Coatings Technology, 166 (2003), 37-43, doi:10.1016/S0257-8972(02) 00740-5

${ }^{8}$ K. M. Doleker, A. C. Karaoglanli, Comparison of oxidation behavior of YSZ and $\mathrm{Gd}_{2} \mathrm{Zr}_{2} \mathrm{O}_{7}$ thermal barrier coatings (TBCs), Surface and Coatings Technology, (2016), doi:10.1016/j.surfcoat.2016.12.078

${ }^{9}$ F. Pusavec, H. Hamdi, J. Kopac, I. S. Jawahir, Surface integrity in cryogenic machining of nickel based alloy - Inconel 718, Journal of Materials Processing Technology, 211 (2011) 4, 773-783, doi:10.1016/j.jmatprotec.2010.12.013

${ }^{10}$ K. Yuan, R. L. Peng, X. H. Li, S. Johansson, Y. D. Wang, Some aspects of elemental behaviour in HVOF MCrAlY coatings in hightemperature oxidation, Surface and Coatings Technology, 261 (2015), 86-101, doi:10.1016/j.surfcoat.2014.11.053

${ }^{11}$ O. Kovářík, P. Haušild, J. Siegl, T. Chráska, J. Matějíček, Z. Pala, M. Boulos, The influence of substrate temperature on properties of APS and VPS W coatings, Surface and Coatings Technology, 268 (2015), 7-14, doi:10.1016/j.surfcoat.2014.07.041

${ }^{12}$ I. Milas, B. Hinnemann, E. A. Carter, Diffusion of Al, O, Pt, Hf, and $\mathrm{Y}$ atoms on alpha- $\mathrm{Al}_{2} \mathrm{O}_{3}(0001)$ : implications for the role of alloying elements in thermal barrier coatings, Journal of Materials Chemistry, 21 (2011) 5, 1447-1456. doi:10.1039/c0jm02212h
${ }^{13}$ J. Liu, Y. H. Sohn, K. S. Murphy, Microstructural evolution of durable thermal barrier coatings with $\mathrm{Hf}$ and/or $\mathrm{Y}$ modified CMSX $-4^{\mathrm{TM}}$ superalloy substrates, Materials Science Forum, 539-543 (2007), Thermec 2006, 1206-1211, doi:10.4028/www.scientific.net/ MSF.539-543.1206

${ }^{14}$ L. Y. Ni, C. Liu, H. Huang, C. G. Zhou, Thermal cycling behavior of thermal barrier coatings with HVOF NiCrAlY bond coat, Journal of Thermal Spray Technology, 20 (2011) 5, 1133-1138, doi:10.1007/ s11666-011-9647-8

${ }^{15}$ C. Zhou, C. Wang, Y. Song, Evaluation of cyclic oxidation of thermal barrier coatings exposed to $\mathrm{NaCl}$ vapor by finite element method, Materials Science and Engineering A, 490 (2008) 6, 351-358, doi:10.1016/j.msea.2008.01.050

${ }^{16}$ S. Laxman, B. Franke, B. W. Kempshall, Y. H. Sohn, L. A. Giannuzzi, K. S. Murphy, Phase transformations of thermally grown oxide on $(\mathrm{Ni}, \mathrm{Pt}) \mathrm{Al}$ bondcoat during electron beam physical vapor deposition and subsequent oxidation, Surface and Coatings Technology, 177 (2004), 121-130, doi:10.1016/j.surfcoat.2003. 08.072

${ }^{17}$ J. A. Haynes, M. K. Ferber, W. D. Porter, Thermal cycling behavior of plasma-sprayed thermal barrier coatings with various MCrAlX bond coats, Journal of Thermal Spray Technology, 9 (2000) 38, 38-48, doi:10.1361/105996300770350041

${ }^{18}$ R. Chen, X. Wu, D. Dudzinski, Influence of thermal cycle frequency on the TGO growth and cracking behaviors of an APS-TBC, Journal of Thermal Spray Technology, 21 (2012) 6, 1294-1299, doi:10.1007/ s11666-012-9824-4

${ }^{19}$ A. El-Turki, G. C. Allen, C. M. Younes, J. C. C. Day, An investigation of the effect of thermal cycling on plasma-sprayed zirconia/NiCoCrAlY thermal barrier coating, Materials and Corrosion, 55 (2004) 1, 24-29, doi:10.1002/maco.200303709

${ }^{20}$ J. Sun, L. L. Zhang, D. Zhao, Microstructure and thermal cycling behavior of nanostructured yttria partially stabilized zirconia (YSZ) thermal barrier coatings, Journal of Rare Earths, 28 (2010) 1, 198-201, doi:10.1016/S1002-0721(10)60 